\title{
Vino de Tea (pine heartwood wine) from La Palma (Spain): ethnographic and physic- chemical characterization of a unique fermented product
}

\author{
Pablo Alonso González * (D) and Eva Parga-Dans
}

\begin{abstract}
This paper presents the results of a novel study of Vino de Tea (pine heartwood wine) from the island of La Palma (Canary Islands, Spain). The aim is to investigate its differential characteristics and contribute to typifying it within the Denomination of Origin 'Wines of La Palma'. The analysis is based on a mixed approach combining a qualitative ethnographic approach (22 interviews) and quantitative physic-chemical methods in a sample of 16 wines. The ethnographical study revealed the tradition and techniques of elaboration behind Vino de Tea. In turn, the physicchemical analysis revealed by chromatography a significant presence of a-terpineol due to elaboration in pine barrels or casks. These samples were compared with a Greek Retsina wine, revealing the differences between these two traditional wines. These data suggest that Vino de Tea is a unique product with distinctive characteristics and potential health benefits, owing to its significant content of a-terpineol resulting from its fermentation in Canary pine casks.
\end{abstract}

Keywords: Wine, Fermented foods, Ethnography, Spain, Pine heartwood wine, Canary Islands, Vino de Tea, Volatile compounds, Vitis viniferae

\section{Introduction}

\section{Context of Vinos de Tea}

Wine is a drink that results from the spontaneous fermentation of grape juice. It originated in the areas of Irak-Iran and Georgia between 8000 and 6000 thousand B.C. Then, wine became an endogenous and traditional drink throughout the Mediterranean, spread by Phoenician and Greek merchants first, and then by the Roman Empire. Winemaking heritage and tradition was well established when Spain initiated its process of colonial and imperial expansion, spreading winemaking culture from California to Chile. This process comprised the conquest of the Canary Islands, formerly inhabited by Berber cultures, throughout the fifteenth century. This

\footnotetext{
* Correspondence: pablo.alonso.gonzalez@ipna.csic.es IPNA-CSIC, Av. Astrofisico Francisco Sánchez, 3, 38206 San Cristóbal de La Laguna, Santa Cruz de Tenerife, Spain
}

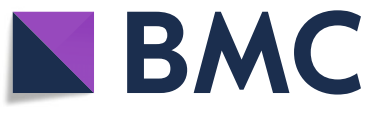

(อ The Author(s). 2020 Open Access This article is licensed under a Creative Commons Attribution 4.0 International License, which permits use, sharing, adaptation, distribution and reproduction in any medium or format, as long as you give

appropriate credit to the original author(s) and the source, provide a link to the Creative Commons licence, and indicate if changes were made. The images or other third party material in this article are included in the article's Creative Commons licence, unless indicated otherwise in a credit line to the material. If material is not included in the article's Creative Commons licence and your intended use is not permitted by statutory regulation or exceeds the permitted use, you will need to obtain permission directly from the copyright holder. To view a copy of this licence, visit http://creativecommons.org/licenses/by/4.0/. led to the beginning of the different winemaking cultures in the archipelago.

Today, the Canary Islands are a subtropical Spanish region near the Atlantic coast of the Sahara, with a long and varied winemaking tradition attested by writers, intellectuals, and experts. Their climate, geography, and natural and cultural characteristics render them unique in terms of winemaking variety and uniqueness, including the absence of the Phylloxera parasite that swept through all European historical vineyards. Moreover, wine is a cornerstone of the Canarian economy and culture, representing a strategic part of the regional GPD [1]. The island of La Palma stands out for its huge geological, geographical, and biological diversity due to unique microclimate and soil compositions (see Fig. 1). Moreover, it presents a unique ethnic composition due to the influence of Portuguese colonists during the 


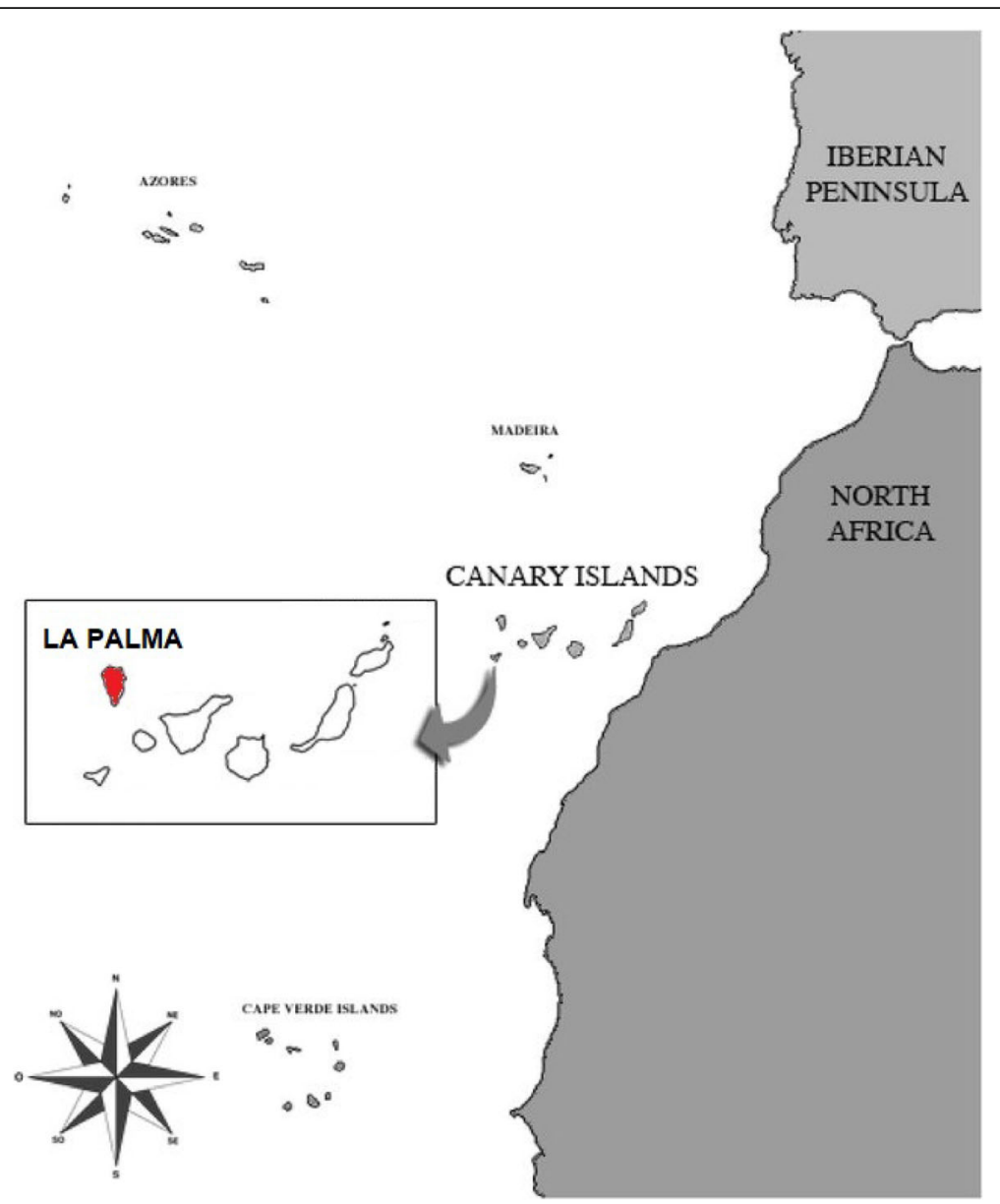

Fig. 1 Location of La Palma, at the north-western end of the Canarian archipelago. It has a surface of $762 \mathrm{~km}^{2}$ and currently has 83,000 inhabitants. The south of the island is characterized by internationally famous sweet Malvasía production and coastal viticulture. In turn, the northern area includes the municipalities of Tijarafe, Puntagorda, and Garafía. It presents high-altitude 'heroic' vineyards between 800 and $1600 \mathrm{~m}$ above sea level. Source: authors

conquest of the Canarian Archipelago in the fifteenth and sixteenth centuries. This has made a large share of traditional winemaking vocabulary deriving from Portuguese rather than Spanish. A significant ecological diversity of minority and rare red and white Vitis viniferae varietals predominate in the island. The major varieties harvested in 2018 were Negramoll, (400 t), Listán Blanco (381 t), Albillo Criollo (174t), Listán Negro (131 t), Listán Prieto $(67 \mathrm{t})$, Vijariego Negro $(55 \mathrm{t})$, Castellana Negra (20 t), Vijariego Blanco (17 t), Malvasía Aromática Seca (15t), and minor amounts of Bastardo Negro, Bastardo Blanco, Forastera Blanca, Gual, Malvasía Aromática Dulce, Marmajuelo, Moscatel, Negramoll Mulata, Pedro Xiemez, Sabro, Tintilla, and Verdello.

What makes this northern area unique, however, is the traditional method of elaboration that results in Vino de Tea (hereafter VT), which literally means 'pine-heartwood wine'. This traditional winemaking elaboration was part of a self-consumption strategy resulting from a sustainable adaptation to the environment in a rather historically isolated environment. VT have been officially recognised as a traditional wine by the Denominación de Origen Vinos de la Palma (DOVP) since 1993. Tea is the resinous heartwood of the autochthonous Canary pine Pinus canariensis used to make the casks wherein wine was aged and preserved (Fig. 2). This endemic conifer is also highly resistant, which explains its former use as traditional construction material. Its cultural imprint is reflected in historical, cultural, and religious traditions, as well as place names [2]. The etymology of the Spanish word tea comes from the Latin taeda, which means resinous pine (and torches made from it), as does the tayda of the former Berber inhabitants of the Canary Islands [3]. This unique trait gives VT their characteristic resinous aroma and flavour. Despite possessing similar resinous traits to the world-famous Greek Retsina wines (with more than 2000 years of history), VT differs greatly. First, Retsina wines have been produced by 
adding resin directly to the wine in earthenware amphorae and later oak casks, and second, Retsinas are not stored in pine casks to preserve and age the wine [4].

Moreover, resin from pine heartwood confers different fermentative qualities on wines, making them unique. The properties of these casks are not dissimilar to other traditional fermentation processes, providing benefits such as improved bioavailability of some nutrients; destruction of antinutritional compounds such as tannins, phytates, and polyphenols; and inhibition of spoilage and pathogenic microorganisms facilitated by the low $\mathrm{pH}[5,6]$.

\section{Previous research and necessity of this investigation}

The need for this study is justified by the threat of disappearance of VT, which has undergone a significant decrease in commercial production, from 9450 in 2007 to a scarce $1350 \mathrm{l}$ in 2018 and $2600 \mathrm{l}$ in 2019. The threat to the survival of VT is due to a number of issues. First, there is a reduction in area and gradual disappearance of traditional vineyard cultivation, due to the adoption of modern techniques involving mechanization and intensification. Second, the generation of vine growers and winemakers connected with the tradition of VT is old and mostly at the verge of retirement. Third, there is a loss of the material heritage associated with VT, including know-how, artisanal coopering techniques of cask making and repair, and traditional cellars, vats, and presses. Finally, there is a decrease in consumption of VT because it is associated with the taste of older generations. Younger generations prefer other kinds of wine, and VT has not been marketed to achieve a position as a highly valorised and unique foodstuff among the thriving tourism economy of La Palma. Only four professional wineries and a few artisanal wineries currently produce VT, the latter for self-consumption only (Fig. 2).

This precarious situation therefore clearly justifies this study to identify the differential characteristics of this unique fermented product and to contribute to its typification within the DOVP. The results reveal that each producer uses a different method, but they also share some common traits in terms of the grapes, casks, and methods employed. Our study also found that the organoleptic quality that makes VT unique is closely associated with the increased presence of $\alpha$-terpineol $\left(\mathrm{C}_{10} \mathrm{H}_{18} \mathrm{O}\right)$ in particular. This is a monocyclic monoterpene tertiary alcohol naturally present in various plant species, particularly pines, with potential health benefits [7-9]. These include antiproliferative, antihypertensive, and anti-inflammatory properties and a characteristic aroma $[10,11]$.

The lack of previous research makes this investigation even more necessary. In the field of the humanities and social sciences, only recently some books and papers

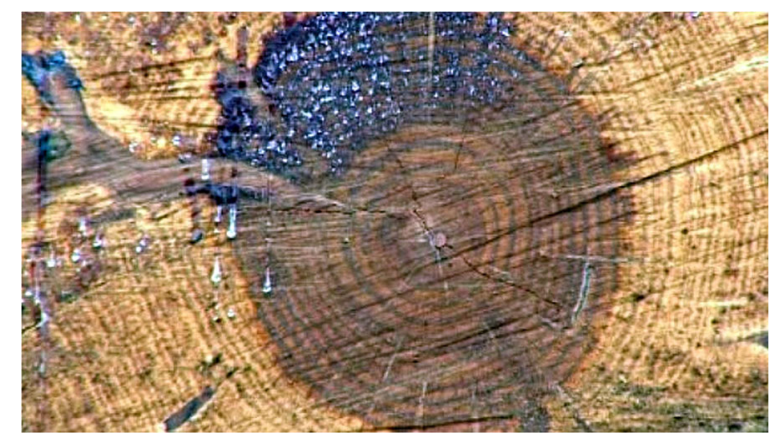

Fig. 2 Detail of the heartwood of the Canary pine or Pinus Canariensis, a protected tree species in the archipelago. Its wood shows a sharp contrast between the sapwood, or outer part, and the heartwood, or inner part. The first is soft and yellowish-white in colour; the inside, the tea, is very resinous and has a reddish colour. It takes at least 30 years for the tree to start forming tea. The tea is practically incorruptible and solid, and has always been highly prized in construction. Source: authors

have started to address wine culture and tradition in the Canary Islands from an ethnographic perspective. The most complete is the monograph by Pastor and Villaseñor [12], followed by some relevant local studies [1318]. The natural sciences have dealt more extensively with Canary wine typologies and how to objectify them, but always dissociating this organoleptic typicity from the heritage and popular culture components always associated with wine. Most studies typify wines according to basic physical-chemical parameters (alcoholic strength, acidity, sulphites, and sugars), which support the regulations of the eleven Denominations of Origin that certify the origin and 'quality' of these wines [19]. In all these accounts however, VT are only mentioned in passing, and mostly described as an exotic product.

There is only one study focusing specifically on VT, dating back to 1997 [20]. It analysed 18 samples, all collected on the same date in artisanal wineries during the 1997 harvest. The authors concluded that the set of factors analysed did not permit the typification of VT, mainly because of the different combinations of white and red varieties and elaboration methods. First, they found that colour was not a suitable criterion: rosés and clarets prevailed but other VT could be considered reds. Second, their physic-chemical analysis of VT including $\mathrm{pH}$, total acidity, tartaric acid, alcohol content, reducing sugars, polyphenols, and colour parameters showed no clear differences from non-VT wines. Third, the results of the tasting panel they set up to assess VT were contradictory. The best general scores were obtained by 'modern' winemaking procedures, whereby the musts were fermented in stainless steel vats then transferred to pine casks for a short period (10 to 30 days). However, the best overall score was obtained by a 'traditional' VT, whose production method involved fermentation and 
long-term ageing in pine casks. The only two commonalities they found among VT wines were the low levels of sulphites, aided by the preservative capacity of pine resins as antibacterial and antifungal, and the harvest time based on the optimal ripening time of Negramoll grapes. Thus, the results were inconclusive regarding the typification of VT: firstly, because the authors did not establish correlations between cultural and natural factors, i.e. between modes of elaboration and physicchemical patterns derived from analysis of samples, and second, the physic-chemical analysis focused on parameters similar to other wines, leaving undetected the unique properties of VT.

This is thus the first comprehensive study of VT from a combined qualitative and quantitative approach. Based on the lessons learnt from the previous study, the background for this research is the interest of various professional wineries and public institutions in typifying VT, given that there are currently different criteria to define VT according to each producer and the DOVP. The aim is to position VT as a highly valorised and unique foodstuff within the thriving tourism economy of La Palma and to revert the current situation of abandonment and decreasing production. Indeed, to declare a VT as 'typical' by the appellation it must go through both physicchemical and subjective tests. Wines must fulfil certain criteria in terms of alcohol and sulphite content, and volatile acidity, among others, as well as undergoing a tasting panel of various wine experts who decide whether it qualifies as VT or not. This 'subjective' phase often raises contradictory opinions among wine tasters [21]. Thus, the aim of this study was to develop a more profound typification of VT. In this direction, the research aim of this project focused on the physicchemical and cultural parameters defining typicity, which would permit the establishment of differentiation criteria for VT and contribute to its preservation, valorisation, and future sustainability. The expected practical result is to establish functional criteria for differentiation of VT by tasters, institutions, producers, and consumers, a little known food product otherwise at the verge of disappearing.

\section{Methods}

This paper reports the results of the first study of the physic-chemical characteristics of VT. The purpose is to develop a precise typification of VT based on a correlation between ethnographic data and physicchemical analyses of wine samples to examine their volatile composition. The strategy was developed taking into account the particular case of VT, fundamentally the impossibility of simulating the many similar fermentation and ageing conditions and varieties used in all the samples studied. The investigation combined ethnographic and biochemical approaches in order to establish a precise correlation between the production methods and conditions for each specific VT and its analytical results.

The biochemical approach focuses on the volatile composition of VT. Although several parameters may play a role in wine characterization, volatile composition is considered the most important [22, 23]. Wine aroma is determined by a complex balance of various volatile compounds [22]. These are responsible for the primary or varietal aroma of the wines and play a key role in differentiating the wines according to grape variety, production area, and climatic factors. Volatile compounds responsible for the secondary or 'fermentative' aroma of wine compounds are obtained during alcoholic fermentation and their production is closely related to the yeasts involved [23]. These volatile compounds are mostly terpenes, which contribute fruity or floral notes to the aroma. The presence and concentration of varietal aromatic compounds has been used for the differentiation and characterization of wine, in conjunction with secondary aromas [24]. The final net contribution of all these compounds to the final aroma depends on whether their concentration in the wine is above the perception threshold [25].

The purpose of the qualitative ethnographic approach was to understand the traditions, values, and know-how related to VT. This allowed us to determine and compile the different elaboration methods, choose the VT samples accordingly, and better interpret the physicchemical analysis of the samples [26, 27]. The methodology employed was more specifically ethno-agronomic, which sees wine as the result of a historical process associated with a cultural and natural landscape shaped by human work upon the environment [28-30]. The main methods of data acquisition were oral history and formal interviews with twenty-two winemakers and other professionals. The strategy for data collection was a snowball sampling approach with semi-structured interviews, whereby interviewees had room to express their views freely while our main themes of interest were also presented [31]. The interviews were then transcribed and processed through software for qualitative analysis (NVivo) to facilitate their interpretation.

Sixteen wine samples were collected between February 2018 and May 2019, comprising 14 VT, a control wine fermented in stainless steel before its ageing in Tea casks, and a Greek Retsina wine for comparison purposes (see Table 1). Retsina from the Aigealeia region of Greece was chosen because of its traditional elaboration from Roditis grapes in amphorae with the addition of resin from Pinus brutia (Aleppo pine), also used in antiquity as sealant to prevent spoilage. The samples were then submitted to a physic-chemical analysis to explore 
Table 1 Description of samples. Samples 1 to 10 were collected from non-professional cellars whose production is destined for selfconsumption. Samples 11 and 16 were control samples taken from a professional cellar, before and after the wine aged in Tea barrels. Samples 12, 13, and 14 were collected from tea wines produced by professional wineries. Finally, sample 15-R is a Retsina wine bought from the cellar in Greece in order to compare it with tea wines. Source: authors

\begin{tabular}{|c|c|c|c|c|}
\hline Sample & Vintage & $\begin{array}{l}\text { Grape } \\
\text { Varieties }\end{array}$ & Fermentation & Ageing \\
\hline 1 & 2018 & Prieto $(90 \%)$ & Tea (1 month) & Chestnut \\
\hline 2 & 2018 & $\begin{array}{l}\text { Almuñeco } \\
(90 \%)\end{array}$ & $\begin{array}{l}\text { Stainless steel } \\
\text { (1 month) }\end{array}$ & $\begin{array}{l}\text { Tea (1 month ) } \\
\text { - Stainless steel }\end{array}$ \\
\hline 3 & 2016 & $\begin{array}{l}\text { Negramoll } \\
\text { and mix of } \\
\text { varieties }\end{array}$ & $\begin{array}{l}\text { Stainless steel } \\
\text { (1 month) }\end{array}$ & Tea (3 years) \\
\hline 4 & 2016 & Mix & Tea (3 months) & Stainless steel \\
\hline 5 & 2017 & Mix & Tea (3 months) & Stainless steel \\
\hline 6 & 2018 & $\begin{array}{l}\text { Vijariego, } \\
\text { Almuñeco, } \\
\text { Albillo }\end{array}$ & Tea (1 months) & Stainless steel \\
\hline 7 & 2018 & Mlx & Tea (3 months) & Stainless steel \\
\hline 8 & 2016 & Mix & Tea & Tea (1 year) \\
\hline 9 & 2018 & Red Varieties & Tea (1 month) & Stainless steel \\
\hline 10 & 2018 & Red Varieties & Tea (1 month) & Stainless steel \\
\hline $\begin{array}{l}11 \\
\text { (Control 1) }\end{array}$ & 2018 & $\begin{array}{l}\text { Vijariego, } \\
\text { Albillo }\end{array}$ & Stainless steel & Stainless steel \\
\hline 12 & 2016 & Red Varieties & Stainless steel & Tea (15 days) \\
\hline 13 & 2017 & Mix & Stainless steel & Tea (20 days) \\
\hline 14 & 2017 & Red Varieties & Stainless steel & Tea (22 days) \\
\hline $\begin{array}{l}\text { 15-R } \\
\text { (Control 2) }\end{array}$ & 2017 & Roditis & Amphorae & $\begin{array}{l}\text { Amphorae and } \\
\text { retsina ( } 6 \\
\text { months) }\end{array}$ \\
\hline $\begin{array}{l}16 \text { (Post- } \\
\text { Control 1) }\end{array}$ & 2018 & $\begin{array}{l}\text { Vijariego, } \\
\text { Albillo }\end{array}$ & Stainless steel & Tea (3 months) \\
\hline
\end{tabular}

their volatile aromatic profile, including monoterpenes, polyoxygenated terpenes, C13 norisoprenoids, alcohols, volatile phenols, and C6 and carbonyl compounds [32]. The volatile aromatic compounds were separated using solid phase extraction (SPE) cartridges (Bond Elut-ENV, $500 \mathrm{mg}, 6 \mathrm{ml}$ ) from $100 \mathrm{ml}$ samples of wine.

\section{Results and discussion}

\section{Historical knowledge about VT}

The history of VT remains mostly unknown, as the key archives of northern La Palma have suffered various fires. We know that the first cultivars arrived on the island in 1505, when the Spaniard Juan Cabrera planted 
them in Los Llanos. Vine plantations and winemaking expanded in the northern areas of Tijarafe and Puntagorda, thanks to the arrival of Portuguese settlers with their own cultivars, and indeed winemaking vocabulary in La Palma employs many Portuguese words. In a way, then VT is the result of the ethnic mixing between Spanish and Portuguese immigrants. In the isolated areas of the north, pine casks were for centuries the only way of preserving and ageing wine, mostly for family consumption within a self-sufficient economy. Commercial records show the important role played by exports of Malvasía wine from southern La Palma without mentioning VT, considered by most locals a low-quality wine until the present. Oral history only allowed us to document a low-grade trade in VT from Puntagorda and Garafía to the eastern town of Los Sauces, where VT were highly appreciated by wine consumers (Fig. 3).

\section{Modern and traditional elaboration and winemaking}

The 14 VT samples and the control wine fermented in stainless steel come from high-altitude vineyards in the north-western area of La Palma at between 800 and $1600 \mathrm{~m}$ above sea level (see Fig. 4), in a region characterized by basaltic lava soils typical of this volcanic island. The average temperature is $20^{\circ} \mathrm{C}$ in summer and $18^{\circ} \mathrm{C}$ in winter, with a concentration of rainfall in the month of December and almost drought conditions throughout the rest of the year. The VT samples present a mixture of the dominant grape varieties in the north-west of La Palma, namely Negramoll, Listán Blanco, Prieto, Albillo, and Almuñeco. The white varieties Listán Blanco and Albillo ripen earlier and both provide sugar, the Albillo acidity. The red varieties Almuñeco and Prieto are earlier than Negramoll and provide colour and acidity, while

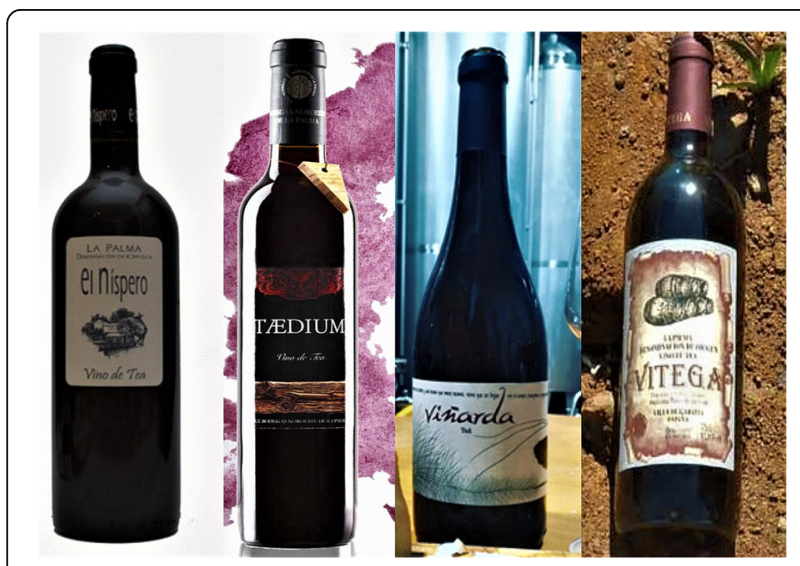

Fig. 3 Commercial brands of Vino de Tea in 2020 sampled in the study. From left to right, El Níspero, Taedium by Vega Norte, Viñarda, and Vitega. The tea made by Viñarda en 2019 was employed as control sample before and after ageing in tea. Production is limited and lack of commercial viability threatens the survival of this traditional wine. Source: authors

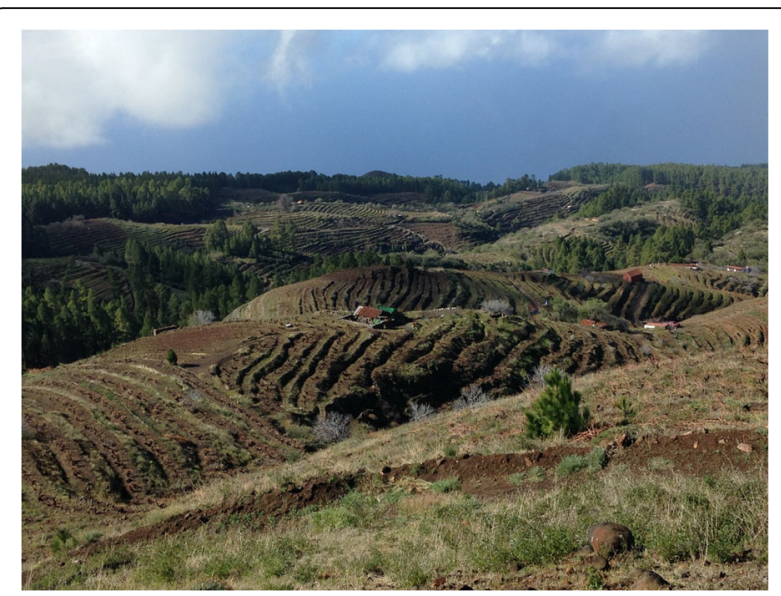

Fig. 4 High-altitude vineyard in northern La Palma. The island holds one the highest vineyards in the world, and the highest in Spain and Europe, ranging between 700 and $1600 \mathrm{~m}$ high. This allows grapes to reach the necessary acidity to produce quality wines. Tea wines were traditionally produced with mixtures of grapes from these vineyards. Source: authors

Negramoll makes up the bulk of the wine, providing acidity and sugar depending on the harvest conditions.

VT samples can be divided between 'modern' and 'traditional' elaborations. Modern VT production from four professional wineries (samples 12, 13, 14, and 16) follows a winemaking protocol involving the mixture of white and red grapes. After destemming and crushing, the musts then ferment in stainless steel tanks. After fermentation ends, wines are racked into a 'clean' tank, and then transferred to a Canary pine heartwood (Tea) cask for a brief period ranging between 20 days to a month, to be finally filtered and bottled. Common oenological additives such as sulphites, yeasts, and tartaric acid are employed.

Although the traditional production of VT has been largely lost, it is still possible to find winemakers producing it in a very similar way. According to traditional VT producers, there was no single form of traditional production, but rather a shared way of doing things with variations among families, producers, and areas, resulting from adaptations to different landscape and weather conditions, available techniques and materials, and to the tastes of each. Traditional elaborations from nonprofessional wineries (samples 1 to 10) follow fermentation methods both in Tea casks and stainless steel deposits at artisan cellars that employ few oenological products (mainly sulphites) or technological appliances (e.g. machines such as destemmers and stainless steel vats). The main difference compared with professional cellars is the ageing time in Tea casks (from 1 month to 3 years), but also aspects including the number of successive uses of casks, and the degree of 'cleaning' of the cask after it is emptied (less technology and chemical 
products), as the more abrasion of the inside of the cask, the more resin it will impart to the wine from the new harvest. The data collected during our ethnographic fieldwork allow us to present a brief summary of the traditional elaboration method of VT.

Normally, the harvest took place when the Negramoll grape reached optimal ripening, the other varieties also being collected on that date. The grapes were then taken to small stone cellars from which the large beam of the press use to protrude through a small window. The cellars were located near the vineyards, which facilitated both the transport of the grapes and the maintenance of a cooler temperature throughout the year. Here, the grapes were first traditionally trodden in a wine press, usually made of $T e a$, and then further crushed in a large press with a horizontal beam of Tea (see Fig. 5). The wine was then transferred to a smaller wine tank or lagarete where the must fermented, or was passed directly to the Tea barrels or casks. Generally, the wine began to ferment in the lagarete itself, and the process lasted a total of about 2 or 3 days. This means that the wine was made with a short maceration and little extraction of colour and phenolic compounds, which is common throughout the Canary Islands. The must was passed to the tea casks where it fermented. Some producers carried out racking to clean it, but this was not a commonplace practice.

After fermenting, the wine started to be drunk immediately. Usually three holes were drilled to open the casks, starting from the top of the barrel to the bottom, where the lees accumulated. The preservation capacity of the resin allowed a good conservation of the wine from its elaboration between September and October, until the arrival of the summer heats, when refermentations could occur due to the presence of residual sugar, and the consequent lack of protection of the wine led to its oxidation, acquisition of acetic flavours, or turning into vinegar. This occurred because wines remained in

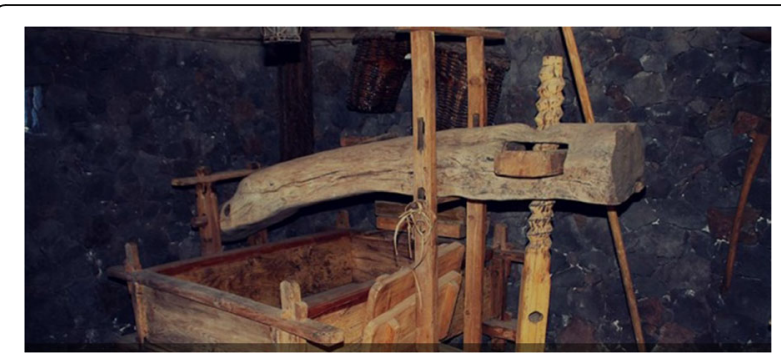

Fig. 5 Winepress made of tea. Winepresses consisted on a large beam and a spindle. The wine was bundled together with a tight rope forming the so-called 'queso' (cheese) before pressing the wine. The wine then fermented with stems and skins in a basin or 'lagarillo' before being transferred to the tea casks, or it could also ferment within the tea casks immediately after crushing the grapes. Source: authors the cask until finishing, and no oenological preservatives were employed. Indeed, it was a common saying that VT travelled badly, first in wineskins made of goat, and more recently in glass jugs.

When the wine ended, the casks were prepared for the next harvest, by washing their interior with sea water, and disinfecting with sulphur candles. Chains were also used to scratch the tartaric attached to the barrels, the abrasion exposing new resin betas that made the cask look like new, giving the wine a lot of flavour again. This period was also employed to repair them, a task carried out by specialist coopers who are no longer available. In fact, no one manufactures new pine casks, and only two or three carpenters are currently able to repair them. This explains why most of those used to make VT exceed 100 years old. Traditionally, when cask staves or metal parts were broken, coopers would travel to the location of the cask with their repair equipment to adjust them.

The elaboration of the casks was carried out in a similar fashion: coopers used to travel on demand to make new casks, instead of having their own workshops. Cask crafting required a good knowledge of the wood of the Canarian pine: it was necessary to make 'samplings' to check the state of the wood. The quantity and quality of tea that could be extracted would determine the size and capacity of the cask, which consequently lacked a standard. The tea was burned on the fire or on the grill, slowly, to make the staves soften and mould better when girting them, until their final touch (see Figs. 6 and 7).

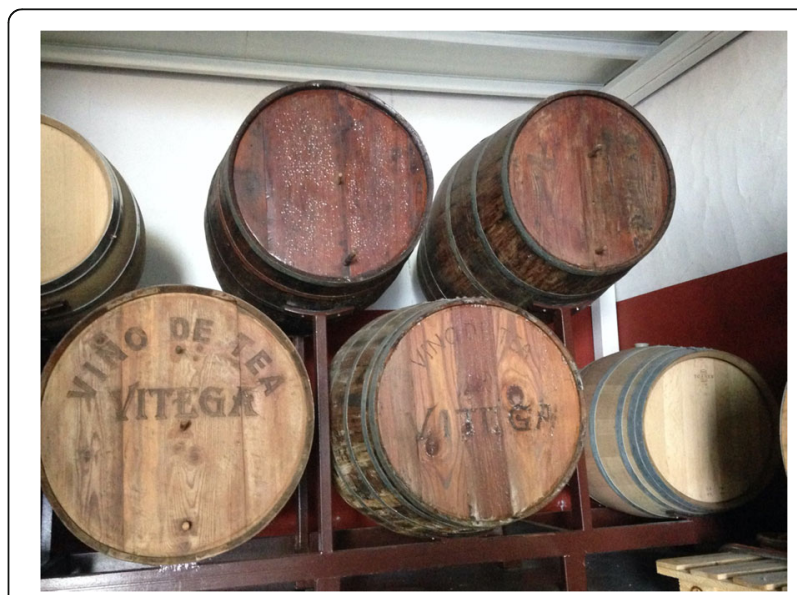

Fig. 6 Tea casks and detail of resin protruding from an old cask. Tea casks are living cultural heritage, as it was common for casks to pass from father to son, or for grandparents to donate them in life to his or her descendant with the most interest in winemaking or viticulture. This explains why, despite the fact that many young people in the area no longer consume VT regularly, they continue to make it out of tradition and as a sign of respect to their elders, living or deceased. Source: authors 


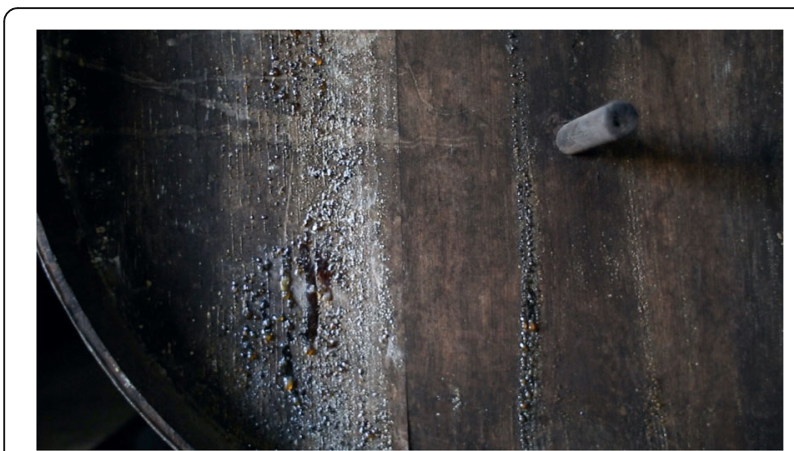

Fig. 7 Tea casks (Fig. 6) and detail of resin protruding from an old cask (Fig. 7). Tea casks are living cultural heritage, as it was common for casks to pass from father to son, or for grandparents to donate them in life to his or her descendant with the most interest in winemaking or viticulture. This explains why, despite the fact that many young people in the area no longer consume VT regularly, they continue to make it out of tradition and as a sign of respect to their elders, living or deceased. Source: authors

\section{Physic-chemical characterization}

The purpose of the analyses was to develop a precise typification of VT through correlating ethnographic data with physical-chemical study of their volatile composition. The methodological strategy was implemented taking into account the peculiarities of VT, fundamentally the impossibility of simulating similar fermentation and ageing conditions in all wines, or even fermentation with similar varieties. One of the most interesting compounds in the light of this study is $\alpha$-terpineol, a volatile monoterpenoid alcohol with a wide range of antioxidant, anticancer, anti-inflammatory, anticonvulsant, antiulcer, and antihypertensive applications, among others [10]. It aids natural winemaking processes due to its preservative and insecticidal properties, which could explain why VT are well preserved without generating excessive volatile acidity and adds lilac aromas to wine. Although $\alpha$ terpineol is naturally occurring in pine resin [33], the exact mechanism through which its tea casks confer it to wines remains unknown. However, results show a clear correlation between increasing $\alpha$-terpineol content and more ageing time in pine heartwood casks. In fact, an artisanal wine aged in Tea for 3 years presented $23248 \mu \mathrm{g} / \mathrm{l}$ (T3), while samples from commercial wineries, which age wines in Tea for only 20 or 30 days, show only $289 \mu \mathrm{g} / \mathrm{l}$ (T12), $631 \mu \mathrm{g} / \mathrm{l}$ (T13), and $109 \mu \mathrm{g} / \mathrm{l}$ (T14) (see Fig. 8). Moreover, the control sample fermented in a stainless steel vat (T11) reveals the direct relationship between time spent in Tea and $\alpha$-terpineol content, with $78 \mu \mathrm{g} / \mathrm{l}$ (T11) before its ageing, and $1197 \mu \mathrm{g} / \mathrm{l}$ (T16) after spending 3 months in such a cask. In any case, the results show high concentrations of $\alpha$-terpineol in all cases, exceeding the mean values $135-250 \mu \mathrm{g} / \mathrm{l}$ found in previous investigations [34]. In fact, no experimental variable exceeded $400 \mu \mathrm{g} / \mathrm{l}$ in any wine [35].

However, many other compounds are specific to VT. This is the case of linalool (3,7-dimethyl-1,6-octadien-3ol), a combination of two enantiomers of a naturally occurring terpene alcohol common in more than 200 vegetal species, including pine. This is a monoterpene that hints towards the sensory perception of green, floral, and spicy attributes (e.g. menthol and aniseed aromas), especially in concentrations over 25-30 $\mathrm{g} / \mathrm{l}$ [36]. The results of the study show concentrations in all the VT analysed, regardless of the elaboration method (Fig. 9). These concentrations are above average, giving these wines spicy aromas well above the perception threshold. This shows that tea casks also confer linalool compounds to wine, beyond the own linalool content of

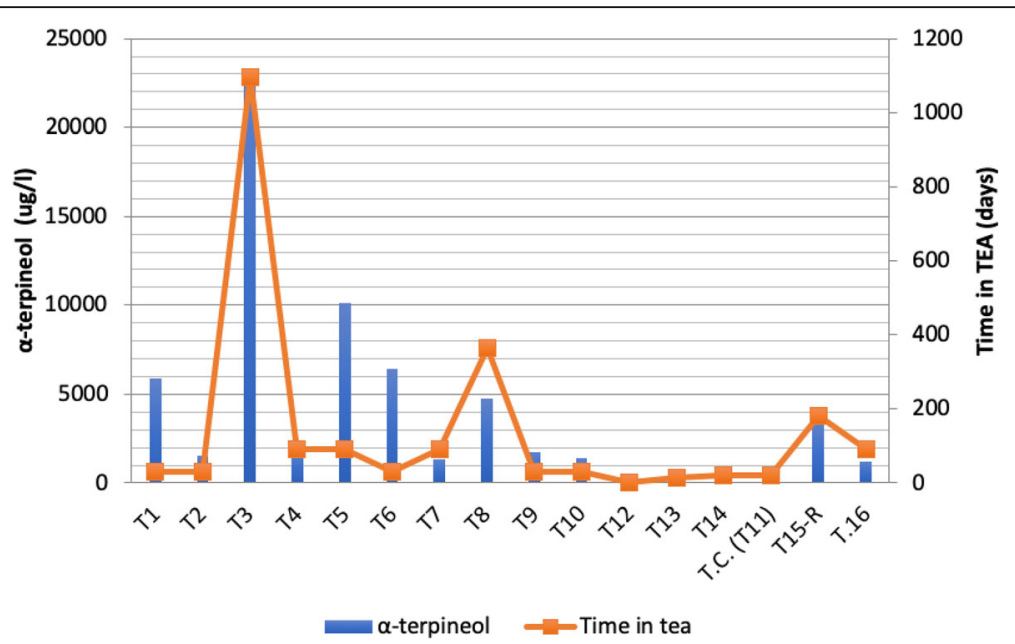

Fig. 8 Tea casks (Fig. 6) and detail of resin protruding from an old cask (Fig. 7). Relation between the time wine ages in tea and content of aterpineol. The analysis demonstrates a clear correlation between time spent in tea casks and a-terpineol content. The most illustrative case is sample T3. This sample spent almost 3 years in a tea cask, and presents extremely high amounts of this resinous compound. Source: authors 


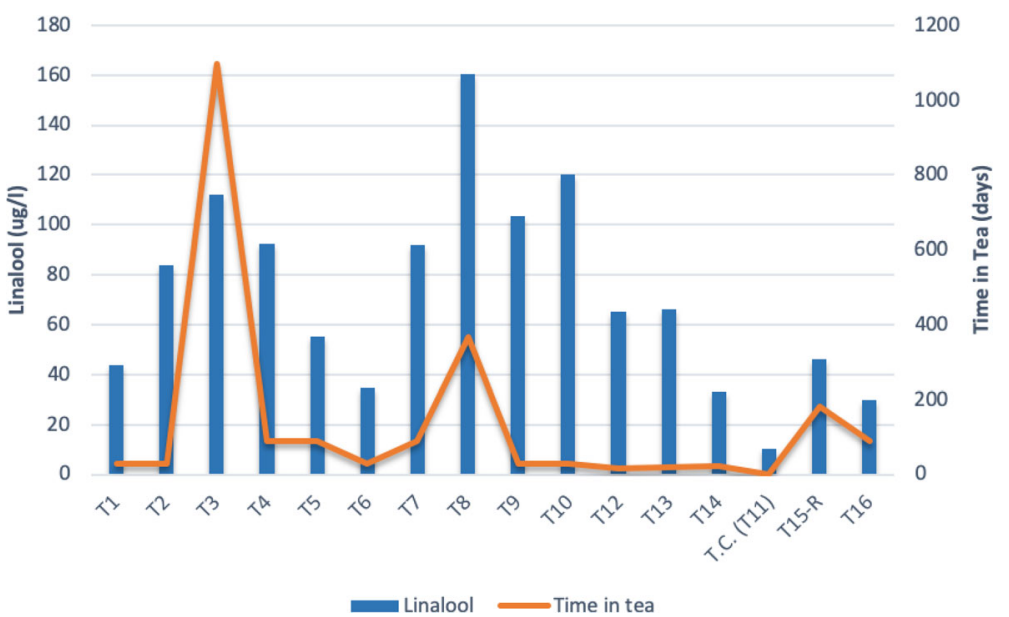

Fig. 9 Relation between the time a wine ages in tea and content of linalool. The correlation between linalool content and time aged in tea casks in clear although not so extreme as is the case of a-terpineol. The analysis shows that a shorter time of ageing in tea casks can induce important changes in the wine. It also points to the relevance of the kind of tea cask and its preparation before ageing wine, as it can confer different properties depending on its age, uses and cleaning process. Source: authors

grapes extracted during fermentation, although the exact reaction mechanism of transfer from cask to wine remains to be explored.

The study can therefore conclude that VT are unique, only distantly similar to Retsina wines, but different from them in terms of physic-chemical character and elaboration procedure.

\section{Conclusions}

Overall, the study gave a contribution for the establishment of differences between traditional and modern winemaking processes of VT, and between VT and other kinds of wines, in view of their potential commercial rebirth. Moreover, this is the first study of the cultural aspects and volatile aromatic compounds of Vinos de Tea or wines aged in pine heartwood casks, from La Palma (Canary Islands, Spain). The aim has been to explore and delineate the cultural and physic-chemical parameters that define the typicity of VT, which would contribute to their preservation, valorisation, and sustainable production and commercialization. In doing so, this survey makes a substantial contribution to the fields of ethnic and fermented foods in Spain, to oenological concerns about unique winemaking processes, and to the broader field of the physic-chemical properties of wine. The study was urgently needed, firstly because the production of VT is on the verge of disappearing. This is mainly owing to the loss of an elder generation that appreciated these wines. Secondly, it is due to the lack of new market niches for its commercialization, as a result of the absence of a clear typification of the wine. Our investigation reveals the uniqueness of VT in terms of elaboration, grapes employed, and physic-chemical properties, as well as the unique health-related benefits associated with its exceptional concentration of $\alpha$ terpineol. The normative implications include the need to better typify and protect VT as a distinctive winemaking tradition by wine organizations in the Canary Islands, and La Palma in particular. In offering a detailed cultural and physic-chemical characterization of VT and showing its different composition from standard wines made in stainless steel deposits or oak casks, and Greek Retsina wines in particular, this survey contributes to the preservation of this unique elaboration tradition. Traditional VT elaboration consisted of a mixture of red and white grapes from the higher altitudes, fermented and preserved in wooden casks made of Canary pine. It was traditionally consumed in the same year of elaboration in the context of self-subsistence economies. The limitations of the study include the lack of historical data to back up the ethnographic and physic-chemical data, requiring further research on the topic. Similarly, more research is needed to shed more light on the influence of pine casks on VT, which requires analysing the other wood compounds in wine beyond the aromatic compounds that are the focus here.

\section{Abbreviations}

VT: Vino(s) de Tea; DOVP: Denominación de Origen Vinos de la Palma

\section{Acknowledgements}

The authors thank all the artisanal and professional wineries in Puntagorda, Tijarafe, and Garafía that kindly donated their wine samples and allocated time for our ethnographic inquiry. We are grateful to VITEC for their collaboration with the analysis.

Authors' contributions

Both the authors contributed equally to this manuscript. The authors read and approved the final manuscript. 


\section{Funding}

This work was supported by the Cabildo de La Palma, the Denomination of Origin Vinos La Palma, IPNA-CSIC, and the Ministry of Science of Spain, project numbers CSO2017-85188-R and RYC2018-024025-I. This manuscript has been edited by Guido Jones, currently funded by the Cabildo de Tenerife, under the TFinnova Programme supported by MEDI and FDCAN funds.

\section{Availability of data and materials}

The authors confirm that the data supporting the findings of this study are available within the article and its supplementary materials.

\section{Competing interests}

The authors declare that there is no conflict of interest regarding the publication of this article.

Received: 22 January 2020 Accepted: 3 September 2020

Published online: 22 September 2020

\section{References}

1. Scherrer P, Alonso A, Sheridan L. Expanding the destination image: wine tourism in the Canary Islands. Int J Tour Res. 2009;11(5):451-63.

2. Afonso L. La toponimia como percepción del espacio: los topónimos canarios. La Laguna: Instituto de Estudios Canarios; 1988.

3. Charco J, Sainz Ollero H. Guía de los árboles y arbustos del norte de Africa: claves de determinación, descripciones, ilustraciones y mapas de distribución. Madrid: Agencia Española de Cooperación Internacional; 2001.

4. Lazarakis K. The wines of Greece. Oxford: Infinite Ideas; 2018.

5. Mortarjemi Y. Impact of small-scale fermentation technology on food safety in developing countries. Int J Food Microbiol. 2002;75(213e29):213-29.

6. Kebede A, Viljoen B, Gadaga T, Narvhus J, Lourens-Hattingh A. The effect of container type on the growth of yeast and lactic acid bacteria during production of Sethemi, South African spontaneously fermented milk. Food Res Int. 2007:40(33e8):33-8.

7. Sabino CKB, Ferreira-Filho ES, Mendes MB, da Silva-Filho JC, Ponte MPTR, Moura LHP, et al. Cardiovascular effects induced by a-terpineol in hypertensive rats. a-Terpineol is effective against L-NAME-induced hypertension in rats. J Flav \& Frag. 2013;28(5):333-9.

8. Lampronti I, Saab A, Gambari R. Antiproliferative activity of essential oils derived from plants belonging to the Magnoliophyta division. Int J Oncol. 2006;29(4):989-95.

9. Held S, Schieberle P, Somoza V. Characterization of a-terpineol as an antiinflammatory component of orange juice by in vitro studies using oral buccal cells. J Agric Food Chem. 2007;55(20):8040.

10. Khaleel C, Tabanca N, Buchbauer G. a-Terpineol, a natural monoterpene: a review of its biological properties. J Op Chem. 2018;16(1):349-61.

11. Hassan SB, Gali-Muhtasib H, Göransson H, Larsson R. Alpha terpineol: a potential anticancer agent which acts through suppressing NF-KB signalling. J Anticancer Res. 2010;30(6):1911-9.

12. Elías Pastor LV, Contreras Villaseñor M. El paisaje del viñedo en las Islas Canarias. El Sauzal: PASOS; 2013.

13. Morales AG, Ojeda AÁR, Torres SH. El cultivo del viñedo como recurso turístico cultural: el caso de la Geria (Lanzarote. Islas Canarias, España). Pap Geogr. 2015;61:109-21.

14. Cabrera ML. La vid y el vino como patrimonio cultural de Canarias. RdM 2014:60:62-70.

15. Hernández AMM. El paisaje vitícola de Canarias: Cinco siglos de historia. Ería. 2005;68:351-64.

16. Arias ML, Benítez RA, Ortega MC. Vinos de Canarias. Canarias: Consejería de Agricultura y Pesca; 1993

17. Lorente A. El valor del patrimonio canario. Mi vino: Vinum. 2018;232:14-5.

18. Solís Robaina FJ. El lagar y la prensa del vino en la historia de Gran Canaria: tipos, funcionalidad y restos arqueológicos (patrimonio enológico). Las Palmas: Universidad de Las Palmas; 2013.

19. Darias-Martín JJ, Andrés-Lacueva C, Díaz-Romero C, Lamuela-Raventós RM. Phenolic profile in varietal white wines made in the Canary Islands. Eur Food Res Technol. 2008:226(4):871-6.

20. Díaz A, González J, Darias Martín J, Bhethencourt Piñero F, Díaz Díaz E, García Pérez A. Los vinos de Tea en la isla de La Palma. Viticultura enología profesional. 2000;70:6-11.
21. Parga Dans E, Alonso González P, Macías VA. Taste and knowledge: the social construction of quality in the organic wine market. Human Eco. 2019; 47(1):135-43.

22. Vilanova M, Martínez C. First study of determination of aromatic compounds of red wine from Vitis vinifera cv. Castañal grown in Galicia (NW Spain). Eur Food Res Technol. 2007;224(4):431-6.

23. Palomo ES, Díaz-Maroto MC, Viñas MAG, Soriano-Pérez A, Pérez-Coello MS. Aroma profile of wines from Albillo and Muscat grape varieties at different stages of ripening. Food Control. 2007;18(5):398-403.

24. Coetzee C, Van Wyngaard E, Suklje K, Silva Ferreira AC, Du Toit WJ. Chemical and sensory study on the evolution of aromatic and nonaromatic compounds during the progressive oxidative storage of a Sauvignon blanc wine. J Agric Food Chem. 2016;64(42):7979-93.

25. Gros J, Lavigne VR, Thibaud F, Gammacurta M, Moine V, Dubourdieu D, et al. Toward a molecular understanding of the typicality of Chardonnay wines: identification of powerful aromatic compounds reminiscent of hazelnut. J Agric Food Chem 2017;65(5):1058-1069.

26. Parga-Dans E, Alonso GP. 'Marketing quality' in the food sector: towards a critical engagement with the 'quality turn' in wine. Geoforum. 2017:85:5-8.

27. Alonso González P, Parga-Dans E. Organic labeling controversies: a means to an end within global value chains. Renew Agr Food Syst. 2018:1-6.

28. Perdomo Molina A. Una propuesta desde la etnoagronomía para acercarnos a la agrodiversidad y la erosión genética de los agrosistemas tradicionales. Agroecología. 2013;7(2):41-6.

29. Alonso González P, Parga Dans E. The 'terroirist' social movement: the reawakening of wine culture in Spain. J Rural Stud. 2018:61:184-96.

30. Alonso González P, Parga-Dans E, Macías Vázquez A. The political economy of wine: how terroir and intra-sector dynamics affect land use in Spain. Land Use Policy. 2017;66:288-92.

31. Sørensen MLS. Between the lines and in the margins: interviewing people about attitudes to heritage and identity. In: Sørensen ML, Carman J, editors. Heritage studies: methods and approaches. New York: Routledge; 2009. p. 164-77

32. Lukić I, Radeka S, Grozaj N, Staver M. Peršurić ĐJFc. Changes in physicochemical and volatile aroma compound composition of Gewürztraminer wine as a result of late and ice harvest. Food Chem. 2016;196:1048-57.

33. Petrakis PV, Roussis V, Ortiz A. Monoterpenoid diversity in relation to morphology of Pinus brutia and Pinus halepensis in an east Mediterranean area (Attiki, Greece): implications for pine evolution. Edinb J Bot. 2000;57(3): 349-75.

34. Roussis V, Papadogianni K, Vagias C, Harvala C, Petrakis PV, Ortiz A. Volatile constituents of three pinus species grown in Greece. J Essent Oil Res. 2001; 13(2):118-21.

35. Baron M, Prusova B, Tomaskova L, Kumsta M, Sochor J. Terpene content of wine from the aromatic grape variety 'Irsai Oliver' (Vitis vinifera L.) depends on maceration time. Open Life Sci. 2017;12(1):42-50.

36. Slegers A, Angers P, Ouellet É, Truchon T, Pedneault K. Volatile compounds from grape skin, juice and wine from five interspecific hybrid grape cultivars grown in Québec (Canada) for wine production. Molecules. 2015;20(6): 10980-1016.

\section{Publisher's Note}

Springer Nature remains neutral with regard to jurisdictional claims in published maps and institutional affiliations.

Ready to submit your research? Choose BMC and benefit from

- fast, convenient online submission

- thorough peer review by experienced researchers in your field

- rapid publication on acceptance

- support for research data, including large and complex data types

- gold Open Access which fosters wider collaboration and increased citations

- maximum visibility for your research: over $100 \mathrm{M}$ website views per year

At $\mathrm{BMC}$, research is always in progress.

Learn more biomedcentral.com/submission 